\title{
Memahami kriteria kualitas penelitian: Aplikasi Pemikiran Penelitian Kualitatif Maupun Kuantitatif
}

\author{
Endang Setiowati ${ }^{1}$
}

${ }^{1}$ Laboratorium Komunikasi dan Radio, Program Vokasi UI, endang.setiowati@vokasi.ui.ac.id

Diterima : 1 Januari 2014

Layak Terbit : 11 Juli 2014

\begin{abstract}
Penghargaan atas quality criteria atau kriteria kualitas atas sebuah penelitian tidak hanya tergantung pada si peneliti, tetapi lebih pada pemahaman para pengujinya akan posisi peneliti tersebut dalam paradigma yang mana. Bukankah skripsi, tesis, dan disertasi itu harus diuji? Usaha keras si peneliti mewujudkan kriteria kualitas penelitiannya akan sia-sia jika tidak nyandak dengan pemahaman para penguji. Seringkali penguji memaksakan kriteria kualitas dari paradigma penelitian yang dianutnya pada penelitian mahasiswa/kandidat yang diujinya padahal berasal dari paradigma yang berbeda. Jadi sejauh mana para penguji memiliki empati pada paradigma dan pendekatan penelitian yang dipakai peneliti merupakan agenda tersendiri dalam menegakkan kriteria kualitas atas sebuah riset
\end{abstract}

Kata Kunci : Quality criteria,paradigma penelitian, penelitian sosial

\begin{abstract}
The value of the quality criteria or quality criteria on a research not based on researcher ability, but rather on understanding the examiners will position researchers in which paradigm. Is not thesis and dissertation must be tested? The researchers endeavor to realize the research quality criteria would be useless if it does not understand by the testers. Often testers impose quality criteria of research paradigm that was followed on the research student or candidate who tested it when coming from different paradigms. The extent to which the testers have empathy on the paradigms and research approaches used by researchers is its own agenda in establishing quality criteria on a study.
\end{abstract}

Keywords: Quality criteria, paradigms of research, social research

\section{PENDAHULUAN}

\section{Latar Belakang}

Ada seorang mahasiswa bertanya pada saya, sebenarnya penelitian yang lebih berkualitas itu penelitian dengan pendekatan kuantitatif atau kualitatif. Sebab banyak yang mengatakan kuantitatif adalah penelitian yang lebih baik kualitasnya dibandingkan kualitatif, karena jumlah orang yang dimintai respon atas pertanyaan peneliti, sehingga disebut responden itu, jumlahnya banyak dan merupakan representasi dari populasi penelitian. Sementara penelitian kualitatif hanya mengandalkan sejumlah kecil orang untuk memberi respon atas pertanyaan peneliti. Namun, penelitian dengan pendekatan kuantitatif tak dapat menjawab mengapa responden tersebut memilih jawaban yang satu dan bukannya yang lainnya. Lalu bagaimana jika si responden merasa tak ada satupun pilihan jawaban yang tersedia cocok dengan apa yang dianggap merupakan jawaban yang paling tepat. Jika begini masalahnya, tentunya penelitian kualitatif yang bisa menjawabnya.

Mendengar pertanyaan dan penjelasan si mahasiswa ini, saya hanya tersenyum karena 
mengingat pertanyaan ini juga merupakan pertanyaan yang saya lontarkan pada dosen saya, almarhum Prof. Dedy Nur Hidayat, PhD (profesor DNH), sewaktu masih mahasiswa. Seperti jawaban professor DNH atas pertanyaan saya dulu, saya menjawab mahasiswa saya, "baik penelitian kualitatif maupun kuantitatif itu sama-sama punya kualitas yang baik, tetapi semua tergantung dari paradigma apa yang digunakan oleh si peneliti sebagai kerangka berpikirnya, juga apa pilihan metodologinya”. Setelah mendengar jawaban saya, tampak wajah mahasiswa itu yang tertegun tanpa ekspresi.
Saya membayangkan ekspresinya persis seperti ekspresi wajah saya dulu ketika mendengar jawaban profesor DNH. Sekilas ketika menelaah apa yang disampaikan oleh prof DNH, bahwa kategori dalam penelitian social akan meliputi beberapa paradigm utama.

\section{Paradigma Utama dalam Penelitian Sosial}

Di dalam penelitian ilmu sosial, terdapat tiga buah paradigma penelitian yang dijadikan kerangka berpikir dari peneliti, profesor DNH mengelompokkan ketiganya sebagai paradigma klasik, konstruktivis, dan kritis.

Tabel 1. Karakteristik dan Kriteria kualitas Paradigma penelitian

KARAKTERISTIK DAN QUALITY CRTERIA PARADIGMA PENELITIAN

\begin{tabular}{|c|c|c|c|c|}
\hline \multirow{2}{*}{$\begin{array}{c}\text { Iraditional' } \\
\text { Positwism/Postpositivism }\end{array}$} & \multicolumn{3}{|c|}{ Consinuctionism/Consthetivism } & \multirow{2}{*}{$\begin{array}{l}\text { Critical Theory } \\
\text { critical theories }\end{array}$} \\
\hline & Constructionism & Constructivism & Critical Constructionism & \\
\hline They & \multicolumn{3}{|c|}{$\mathrm{We}_{\mathrm{e}}$} & You \\
\hline $\begin{array}{l}\text { - Media effects, uses and } \\
\text { gratifications, cultivation, } \\
\text { information theories, etc. } \\
\text { - Media economics, media } \\
\text { functions, ne twork } \\
\text { theories, etc. }\end{array}$ & $\begin{array}{l}\text { - Media and the social } \\
\text { constructions of } \\
\text { realities, theories of } \\
\text { discourse, etc. } \\
\text { - Media and pop culture }\end{array}$ & $\begin{array}{l}\text { - Symbolic interactions } \\
\text { (Chicago school), } \\
\text { audience reception, } \\
\text { theories of meaning, } \\
\text { discourse, cultural } \\
\text { studies, etc. }\end{array}$ & $\begin{array}{l}\text { - Media literacy, media } \\
\text { and genderfife minism, } \\
\text { critical discourse } \\
\text { theonies, critical cultural } \\
\text { studies, media and } \\
\text { politics of identity, media } \\
\text { policy theories ett.) }\end{array}$ & $\begin{array}{l}\text { - Critical political-economy } \\
\text { of media (eg. theories of } \\
\text { hegemony, public } \\
\text { spheres, media } \\
\text { imperialism, media } \\
\text { concentration and } \\
\text { regulation) }\end{array}$ \\
\hline Nomothetic & Nomothetic / ideographic & Ideographic & Ideographic / nomothetic & Ideographic/ nomothetic \\
\hline $\begin{array}{l}\text { Quantitative \& qualitative } \\
\text { (quantitative dominan) }\end{array}$ & Qualitative dominan & $\begin{array}{l}\text { Qualitative } \\
\text { (kecuali Iowa school) }\end{array}$ & Qualitative & Qualitative \\
\hline Objectivity & Trustworthiness & Reflexivity / authenticity & Authenticity: & Historical situatedness \\
\hline Extemal validity & Transferability & Confimability (subjects) & Ontologicaljeducative auth & Enlightenment(conscience) \\
\hline Inte mal Validity & Credibility & & Catalytic authenticity & Empowement(action) \\
\hline Reliability & Dependability & & Tactical authenticity & Holistics \\
\hline Confirmability (objects) & $\begin{array}{l}\text { Confirmability (peer inter- } \\
\text { subject tivity) }\end{array}$ & & $\begin{array}{l}\text { Confimability (subjects - } \\
\text { researcher) }\end{array}$ & Confirmability(theory) \\
\hline $\begin{array}{l}\text { Survey, experiment, case } \\
\text { study, }\end{array}$ & Survey, case study, & $\begin{array}{l}\text { Participatory, ethrography, } \\
\text { e throme thodology }\end{array}$ & $\begin{array}{l}\text { Participatory - action } \\
\text { research }\end{array}$ & $\begin{array}{l}\text { Participatory, action, and } \\
\text { adrocacy research }\end{array}$ \\
\hline $\begin{array}{l}\text { Statistics, comparative } \\
\text { analysis, network, } \\
\text { function, ontent analysis, }\end{array}$ & $\begin{array}{l}\text { Interactional analysis, } \\
\text { document textual analysis, } \\
\text { comparative analysis, etc }\end{array}$ & $\begin{array}{l}\text { Life histories, ethnographic, } \\
\text { explorative-dialogic } \\
\text { analysis, discourse analysis }\end{array}$ & $\begin{array}{l}\text { CDA, ethnographic } \\
\text { analysis, explorative- } \\
\text { dialogic analysis }\end{array}$ & $\begin{array}{l}\text { Historical comparative } \\
\text { analysis, inte rpret tative } \\
\text { analysis, CDA }\end{array}$ \\
\hline
\end{tabular}

- Tabel iri merupakan tabel ciptaan Prof. Deddy Nur Hidayat, PhD berdasarkan berb azai sumber, urtuk mempenihatkan kompleksitas penentuan quality cnterio. (Sumbermya a.l. Denzin and Guba, 1994, 2000, 2005), Crotty (1998), Patton (2002), Mats and Skolberg (2000). Sementara teori-teori dalam Tabel harya ihstrasi, dan tidak mencakup kes ehumhan teor dalam masing-masing paradizma 
Salah satu sumber pemikiran profesor. DNH adalah tulisan Egon G. Guba dan Yvonna S. Lincoln, Competing Paradigm in Qualitative Research (Denzin dan Lincoln, 1994). Dalam edisi 1994 itu, Guba dan Lincoln membagi paradigma ke dalam empat jenis: positivism, post-positivism, critical, dan constructivism. Tetapi dalam edisi 2000, dalam artikelnya Paradigmatic Controversies, Contradictions, and Emerging Confluences, (Denzin dan Lincoln, 2000) membagi paradigma kedalam lima kelompok, di mana Denzin dan Lincoln menambahkan satu paradigma lagi yaitu paradigma participatory.

Paradigma positivism dan post-positivism merupakan paradigma yang menjadi acuan berpikir bagi para peneliti ilmu sosial sejak ilmu sosial pertama kali dianggap penting untuk diteliti sebagai suatu kajian ilmu. Oleh sebab itu professor DNH mengategorikannya sebagai paradigma klasik atau tradisional. Paradigma ini menganggap bahwa ilmu sosial seperti ilmu pasti atau ilmu pengetahuan alam, di mana segala sesuatu dapat diprediksi karena sifatnya yang pasti. Oleh sebab itu pendekatan prediksi ini digunakan dengan mengambil sejumlah sampel yang menjadi representasi dari populasi yang akan diteliti. Penentuan jumlah sampelnya pun diatur dengan suatu kaidah khusus yang mencerminkan representasi dari besarnya jumlah populasi. Pendekatan dalam paradigma ini kemudian disebut sebagai penelitian dengan pendekatan kuantitatif.

Namun sejalan dengan kompleksitas ilmu sosial, mulai muncul pertanyaan seperti yang dilontarkan mahasiswa saya tadi, yaitu mengapa responden tersebut memilih jawaban yang satu dan bukannya yang lainnya. Lalu bagaimana jika si responden merasa tak ada satupun pilihan jawaban yang tersedia, cocok dengan apa yang dianggap merupakan jawaban yang paling tepat baginya? Maka muncul para peneliti yang melakukan penelitian yang dapat menjawab pertanyaanpertanyaan tersebut, namun dengan responden yang lebih sedikit dan dengan teknik wawancara yang lebih mendalam, bukan hanya sekedar pertanyaan dengan pilihan jawaban yang telah tersedia. Para peneliti ini masih menganggap bahwa ilmu sosial itu seperti ilmu pasti, sehingga tujuan peneliti melakukan penelitian adalah untuk melakukan konfirmasi atas teori-teori yang telah ditemukan sebelumnya dengan fenomena yang ia teliti. Para peneliti ini menamakan diri mereka sebagai peneliti dari paradigma post-positivist atau penelitian setelah masa positivis, dan pendekatannya disebut sebagai pendekatan kualitatif.

Dalam ranah komunikasi, perkembangan teknologi komunikasi, industri media, dan globalisasi telah mendorong munculnya dua perkembangan dalam Ilmu Komunikasi:

1. Komunikasi dan media semakin menjadi bagian penting kajian disiplin ilmu-ilmu sosial dan humaniora lainnya (munculnya kajian-kajian sosiologi media, antropologi media, politik media).

2. Re-integrasi kajian-kajian media ke induk atau akar-akarnya dalam berbagai perspektif dan kerangka teori sosialhumaniora a.l. diperlihatkan oleh: 
(a) marak dan menguatnya kembali kajian-kajian komunikasi dan media sebagai bagian dari filsafat, teori-teori kritis, ekonomi mikro, manajemen, ekonomi-politik, dan sosiologi;

(b) munculnya critical studies division dalam asosiasi ilmuwan komunikasi dan media yang semula didominasi oleh perspektif positivism, contohnya, Cultural and Critical Studies Division dalam Association for Education in Journalism and Mass Communication (AEJMC). monolitik, tetapi sebagai kumpulan varian paradigmatik

Dua perkembangan dalam Ilmu Komunikasi ini menimbulkan paradigma lain dalam penelitian ilmu sosial, utamanya ilmu komunikasi, apalagi setelah penelitian kualitatif tidak lagi dianggap sebagai penelitian yang monolitik.

Seperti disebutkan di atas terdapat tiga paradigma utama, namun profesor DNH membagi paradigma konstruktivis menjadi tiga bagian.

Tabel 2 Perbatudingan cara berpikir dan berbilasa berdasarkan metode penelitian

\begin{tabular}{|c|c|c|}
\hline Jenis Mletode & Kosa kata & Implikesi pada temuan \\
\hline Gounded rese axh & Iiscover & $\begin{array}{l}\text { - Merujukkan hal baru vang belim } \\
\text { perrah dingkapkan o.eh rinet } \\
\text { sebelumuya }\end{array}$ \\
\hline Ethrography & $\begin{array}{l}\text { Explain or to seek to } \\
\text { understand }\end{array}$ & $\begin{array}{l}\text { - Mergungkapkan apa yang menjadi } \\
\text { "persaan dan harapan" subyek } \\
\text { penelitian }\end{array}$ \\
\hline Case Sudy & Explore a proces & 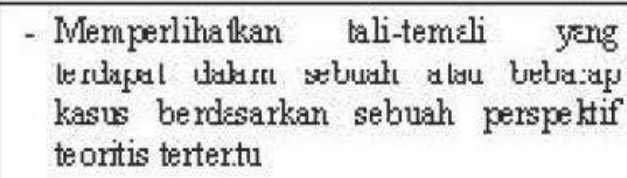 \\
\hline Phe nome nology & $\begin{array}{l}\text { Iescribe } \\
\text { experiences }\end{array}$ & $\begin{array}{l}\text { - Merunjukkan suatu gambaran me ngexai } \\
\text { pengaleman atau suatu fe nome na secara } \\
\text { obyektit dan suiut parudang teor.ts tertertu }\end{array}$ \\
\hline
\end{tabular}

Sumber: Cresswell, 1994.

(c) munculnya mata kuliah dari berbagai perspektif keilmuan, di banyak universitas (khususnya di Amerika Serikat) yang semula amat kuat didominasi tradisi positivism; mata kuliah metode penelitian kualitatif tidak lagi dilihat sebagai metode yang yaitu konstruksionisme yang cenderung mengarah atau mirip dengan paradigma positivis, karena banyak menggunaka cara berpikir positivis, konstruktivisme yang murni, dan konstruksionisme kritis yang cenderung menggunakan kaidah berpikir paradigma kritis/kritikal. (Lihat Tabel 1) 


\section{Metode Penelitian}

Untuk menghindari kriteria kualitas yang otoriter dan monolitik, sesungguhnya tidak hanya berdasarkan paradigma dan jenis teori yang dipakai, melainkan pula menurut metode penelitian yang dipergunakan.

Jika kita mau bersungguh-sungguh menegakkan tradisi ilmiah, sebetulnya setiap paradigma, pendekatan dan metode penelitian memiliki logika dasar dan kosa kata (bahasa) sendiri-sendiri.

Penelitian kuantitatif dengan metode survey memiliki logika dasar hipotetico deductive, yaitu pada riset kuantitatif dengan metode survey lazimnya dimulai dengan adanya sebuah atau lebih konsep sebagai variable penelitian (bebas dan terikat).

Kemudian konsep itu diuraikan (dioperasionalisasikan) hingga tingkat indikator yang atas dasar ini dibuat instrument penelitian (kuesioner). Jadi dalam riset kuantitatitif sebelumnya sudah ada rencana/anggapan (apriori) untuk mengukur/menguji sebuah/lebih variable dalam sebuah populasi (sampel). Bahasa yang lazim dipakai antara lain "hubungan" atau "pengaruh", "tingkat" atau "kecenderungan", "prosentasi” atau "kekuatan" hubugan; dan sebagainya.

Sedangkan, penelitian kualitatif dengan metode yang manapun, umumnya memiliki pola pikir grounded-inductive, yaitu usaha memahami sebuah gejala dari perspektif teori/konsep tertentu. Di sini, konsep (konsep) tidak hendak diuji/diukur dalam sebuah sampel; melainkan dipakai untuk menjelaskan fonomena yang diteliti.
Peneliti dengan demikian sebelumnya peneliti tidak memiliki anggapan (aposteriori); bahkan ia berusaha menemukan "teori” dari gejala yang ditelitinya. Kosa kata yang banyak digunakan antara lain "keterkaitan antar gejala," "makna sebuah gejala" dan "pola yang ditemukan". Dalam tradisi kualitatif bahkan setiap metode penelitian memiliki cara bertutur yang bukan sekadar membedakan antar jenis metode penelitian, tetapi mencerminkan logika dasar yang dipakai dan jenis temuan untuk setiap metode.

Cresswell (1994) juga mengajarkan betapa kualitas sebuah riset bisa dibaca semenjak kita merumuskan masalah penelitian. Sebab, sebagaimana dicontohkannya setiap metode memiliki cara merumuskan masalah yang berbeda satu sama lain. Cara merumuskan masalah dalam kuantitatif; merumuskan untuk univariat berbeda dari multivariat; untuk deskripsi variabel bebas berbeda dari deskripsi variabel antara; untuk multivariat hubungan berbeda dari multivariat pengaruh; dan seterusnya. Demikian pula cara merumuskan masalah dalam penelitian kualitatif: grounded research berbeda dari case study, berbeda dari ethnography, berbeda dari fenomologi.(Lihat Tabel 2)

\section{HASIL DAN PEMBAHASAN}

Banyak di antara mahasiswa, dosen bahkan peneliti yang berpangkat APU (Ahli Peneliti Utama) sekalipun yang masih menyamakan masalah penelitian dengan masalah sosial yang (akan) diteliti. Mereka tidak tahu perbedaan antara perumusan masalah penelitian dan masalah yang ada di lapangan. 


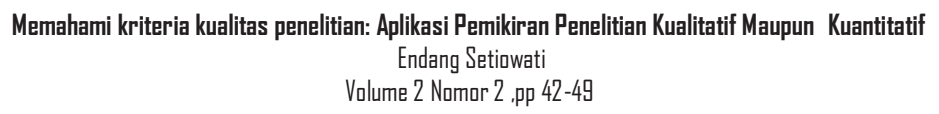

Apalagi kalau harus merumuskan masalah penelitan berdasarkan paradigma dan metode penelitian yang yang dipakai.

Untuk contoh: sebuah masalah sosial, misalnya "Maraknya tayangan infotainmen merajai tayangan yang disajikan oleh stasiunstasiun televisi di Indonesia" Dari masalah sosial ini, apa yang akan dijadikan permasalahan penelitian? Bagaimana kalau Anda diminta membuat perumusan masalah dengan menggunakan paradigma kritis dan memakai metode case study?

Kemampuan merumuskan masalah merupakan keterampilan dasar pertama yang mesti dimiliki oleh peneliti. Sebab jika peneliti tidak bisa atau salah merumuskan masalahnya maka akan berbeda hasil penelitiannya. Kembali ke Cresswell (1994), bahwa setiap metode memiliki caranya sendiri dalam merumuskan masalah.

Tapi apakah perumusan masalah itu? Adalah konseptualisasi dari masalah/gejala sosial yang mau diteliti. Ingatlah bahwa jika bicara konsep berarti kita bicara teori; sebab isi teori adalah konsep-konsep. Dengan kata lain, jika kita hendak membuat perumusan masalah atas sebuah gejala sosial, hendaknya kita menyadari konsep apa (dilihat dari teori apa) yang akan dipergunakan. Kembali ke contoh masalah sosial "Maraknya tayangan infotainmen merajai tayangan yang disajikan oleh stasiun-stasiun televisi di Indonesia", konsep apa yang dipakai dalam membuat rumusan masalahnya? Katakanlah kita gunakan konsep "literasi media" dari Baran. Sehingga boleh jadi rumusan masalahnya menjadi:
1. Adakah hubungan rendahnya tingkat literasi media dari masyarakat dengan maraknya tayangan infotainmen di stasiunstasiun televisi di Indonesia? (Untuk perumusan masalah dengan metode survey bivariat dengan paradigma klasikal)

2. Apakah rendahnya tingkat literasi media dari masyarakat membuat para pengelola stasiun televisi dengan mudahnya menciptakan 'selera pasar' sesuai keinginan mereka, untuk keuntungan para pemilik media? (Untuk perumusan masalah dengan metode fenomenologi dengan paradigma kritikal).

Dari dua contoh di atas, kiranya dapat ditangkap bahwa dalam perumusan masalah sekaligus terangkum empat aspek: masalah sosialnya, konsep/teori yang dipakai, paradigma yang dipergunakan dan metode yang dipilih. Yang penting diperhatikan adalah pemakaian kosa kata yang sesuai dengan metode dan paradigma yang digunakan.

Banyak manfaat yang bisa diraih dengan kemahiran merumuskan masalah. Dengan adanya perumusan masalah yang tepat; peneliti segera tahu kerangka teori yang akan dipakai; paradigma dan metode yang akan dipergunakan serta proses serta hasil riset yang akan dicapai. Jika hal itu dituangkan secara konvensional dalam bentuk tulisan; maka dari perumusan masalah yang tepat akan segera terwujud Bab I (Pendahuluan yang berisi latar belakang masalah, perumusan masalah, dan tujuan penelitian), Bab II (Kerangka Teori), dan Bab III (Metodologi yang berisi paradigma penelitian, 


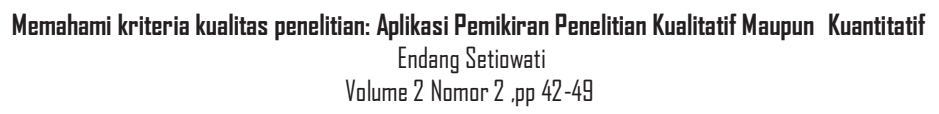

metode penelitian, teknik pengumpulan data, dan teknik analisis data). Jika sudah selesai dan dianggap baik desain penelitian (research design)-nya, barulah siap untuk turun lapangan mengumpulkan data yang dibutuhkan.

Disamping itu, dan justru hal ini menjadi sesuatu yang mendasar dalam rangka mencapai sebuah quality criteria, seandainya Anda sudah tepat membuat rumusan masalah maka hal itu akan menuntun Anda memperoleh hasil (laporan) penelitian yang absah. Bukan saja pada cara memperoleh datanya dan jenis datanya; melainkan cara membahasakannya.

\section{PENUTUP}

\section{Simpulan}

Bagian ini sebenarnya hanya sekadar mengingatkan bahwa penghargaan atas quality criteria atau kriteria kualitas atas sebuah penelitian tidak hanya tergantung pada si peneliti, tetapi lebih pada pemahaman para pengujinya akan posisi peneliti tersebut dalam paradigma yang mana. Bukankah skripsi, tesis, dan disertasi itu harus diuji? Usaha keras si peneliti mewujudkan kriteria kualitas penelitiannya akan sia-sia jika tidak nyandak dengan pemahaman para penguji. Seringkali penguji memaksakan kriteria kualitas dari paradigma penelitian yang dianutnya pada penelitian mahasiswa/kandidat yang diujinya padahal berasal dari paradigma yang berbeda. Jadi sejauh mana para penguji memiliki empati pada paradigma dan pendekatan penelitian yang dipakai peneliti merupakan agenda tersendiri dalam menegakkan kriteria kualitas atas sebuah riset.

\section{Saran}

Tantangan lain datang dari dorongan manusiawi kepada kandidat yang diuji. Bagaimana pun kriteria kualitas ini bersifat impersonal. Sementara sering terjadi dalam proses bimbingan yang terbangun bukan dialog intelektual tetapi terciptanya hubungan emosional antara mahasiswa dan pembimbing. Alhasil, perjuangan menegakkan kebenaran akademik acap terdistorsi oleh sikap manusiawi tersebut. Akhir kata, semoga usaha yang dirintis oleh almarhum Prof. Dedy Nur Hidayat, PhD untuk membangun kualitas riset ini tidak bernasib seperti menegakkan benang basah. 


\section{DAFTAR PUSTAKA}

Cresswell, John W. (1994) Research Design Qualitative \& Quantitative Approaches, Thousand Oaks, London, New Delhi: Sage Publication

Denzin, Norman K and Yvonna S. Lincoln, eds. (2000) Handbook of Qualitative Research (2nd edition), Thousand Oaks, London, New Delhi: Sage Publication

Denzin, Norman K and Yvonna S. Lincoln, eds. (1994) Handbook of Qualitative Research, Thousand Oaks, London, New Delhi: Sage Publication.

Neuman, W. Lawrence. (2003). Social Research Methods: Qualitative and Quantitative Approaches. Boston: Pearson Education, Inc.

Patton, Michael (2002). Qualitative Research and Evaluation Methods. Thousand Oaks, London, New Delhi: SAGE Publication

Jurnal ISKI Vol. III/April 1999

Thesis Jurnal Penelitian Ilmu Komunikasi Departemen Ilmu Komunikasi FISIP UI, No.1/Volume1/2002

Thesis, Jurnal Penelitian Ilmu Komunikasi Departemen Ilmu Komunikasi FISIP UI, Volume III/No.3 September-Desember 2004. 